\title{
Social and Secure?
}

Politics and Culture of the Welfare State: A Comparative Inquiry

EUROPEAN CONTRIBUTIONS TO

This volume offers a comparative and multidisciplinary inquiry into the welfare state settings of the Netherlands, the United States, and Canada. Introductory chapters define the terms and present sociological reflections on the welfare state. Subsequent sections explore the different historical trajectories of the welfare state in the three countries; the literary and filmic renderings of life and culture in the welfare state; and recent welfare politics, including policies, covert motives, and emerging trends.

In twenty-five essays historians, sociologists, policy makers, literary scholars and film critics document the interactions and the differences between the three welfare systems. Their focus is on the United States, where recent developments have commanded the attention of European decision makers.

Their conclusion is that living in a welfare

state need not be social nor secure, and

therefore warrants critical reflection.

AMERICAN STUDIES XXXVII

Edited by:

HANS BAK

FRITS VAN HOLTHOON

HANS KRABBENDAM

Contributors:

EDWARD L. AYERS

EDWARD D. BERKOWITZ

AD BOCKTING

GARETH DAVIES

MEL VAN ELTEREN

EUGENE VAN ERVEN

RICHARD HARDACK

FRITS VAN HOLTHOON

LAWRENCE R. JACOBS

LIAM KENNEDY

S. JAY KLEINBERG

JAAP KOOIJMAN

MARY A. MCCAY

DUCO VAN OOSTRUM

CARL PEDERSEN

DEREK L. PHILLIPS

JOHN RAEBURN

ALI DE REGT

ROBERT SHULMAN

THEDA SKOCPOL

JAMES STRUTHERS

DANIEL H. USNER
In.Eng
J. VAN DER VEEN
KE WAALDIJK
VESPER

\section{Social and Secure?}

Politics and Culture of the Welfare State: A Comparative Inquiry 


\section{SOCIAL AND SECURE? \\ Politics and Culture of the Welfare State: \\ A Comparative Inquiry}

edited by

Hans Bak

Frits van Holthoon

Hans Krabbendam

with contributions from

Edward L. Ayers

Edward D. Berkowitz

Ad Bockting

Gareth Davies

Mel van Elteren

Eugene van Erven

Richard Hardack

Frits van Holthoon

Lawrence R. Jacobs

Liam Kennedy

S. Jay Kleinberg

Jaap Kooijman

Mary A. McCay

Duco van Oostrum

Carl Pedersen

Derek L. Phillips

John Raeburn

Ali de Regt

Robert Shulman

Theda Skocpol

James Struthers

Daniel H. Usner

Romke J. van der Veen

Berteke Waaldijk

John Zvesper
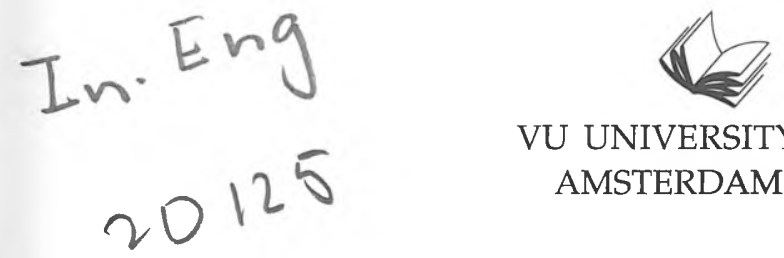

VU UNIVERSITY PRESS

AMSTERDAM 1996

S 


\section{ACKNOWLEDGMENTS}

The essays in this volume were first presented at the annual conference of the Netherlands American Studies Association in the Roosevelt Study Center in Middelburg, the Netherlands, on June 6-8, 1995. Sixty-five scholars from the United States, Canada, the Netherlands, Great Britain, and Denmark gathered to compare the history, workings, and effects of the welfare states in these countries. All but one of the papers are published here.

The editors would like to thank Leontien Joosse and Tjalling de Vries for expediting the editorial process of this volume. Financial assistance to organize the conference and publish the proceedings was provided by the United States Information Service (American Embassy, The Hague), the United States Information Agency (Washington, D.C.), the Association for Canadian Studies in the Netherlands, the Royal Netherlands Academy of Arts and Sciences (Amsterdam), and the Roosevelt Study Center (Middelburg). Without such support the tradition of the annual NASA conferences could not continue.

The editors 